\title{
Characteristics of Composite Rice Straw and Coconut Shell as Biomass Energy Resources (Briquette)(Case study: Muara Telang Village, Banyuasin of South Sumatra)
}

\author{
Muhammad Yerizam ${ }^{1}$, Faizal,M², Marsi $^{2}$, Novia ${ }^{2}$ \\ ${ }^{1}$ Enviromental Science, Sriwijaya University \\ Chemical Engineering Department of State Polytechnic of sriwijaya, \\ Jl. Srijaya Negara. Bukit Besar, Palembang 30139, Indonesia
}

\author{
${ }^{2}$ Department of Chemical, Engineering Faculty, Sriwijaya Univrsity, Indralaya 30662 \\ E-mail: muhammadyerizam@yahoo.co.id; faizal_ga58@yahoo.co.id; mbasihin1960@yahoo.com; noviasumardi@yahoo.com
}

\begin{abstract}
Rice straw and coconut shell as Solid residues are, biomass residue materials that are not optimally used by farmers in Muara Telang and potentially become environmental pollutant. These residues are used as an alternative energy which are biomass briquettes. Post-harvest produced 114 tons yield of rice straw and 80 tons yield of coconut shell. Mostly these residues were burned and produced environmental gas pollutant such as $\mathrm{CO}, \mathrm{CO}_{2}$ and $\mathrm{NOx}$ emissions. Rice straw and coconut shell have carbon compound that contained in the fixed carbon (FC), which flammable and became energy resources. Rice straw has $15.61 \%$ of FC and coconut shell has $78.32 \%$ of FC. Rice straw fuel value is $1525.5 \mathrm{cal} / \mathrm{gram}$ while coconut shell has $7283.5 \mathrm{cal} / \mathrm{gram}$ of fuel value. The fuel value of biobriquette in ratio 50:50 is $4354.50 \mathrm{cal} / \mathrm{gram}$. This fuel value close to coal fuel value between $4000-8000 \mathrm{cal} / \mathrm{gram}$.
\end{abstract}

Keywords - Rice Straw; Coconut Shell; Biobriquette; Fuel Value.

\section{INTRODUCTION}

The Scarcity of kerosene causes higher prices that people in both rural and urban area will be more difficult to find and use it. Nowadays, Rural communities such as in the village of Muara Telang are looking for alternatives fuels to be used. They make utilize $\log$ s and wooden branches that exist around them as fuel. Availability of logs and branches are very limited and will cause damage to forests. Solid waste utilization from the farms and plantations such as rice straw and coconut shell are able to be substitute fuel. Rice straw and coconut shell used to be solid fuel as biobriquette. Both wastes are biomass that have good carbon content and fuel value [1],[2]. Biomass chemical contents that are important to obtain combustion characteristics are the element $\mathrm{C}, \mathrm{H}, \mathrm{O}$, $\mathrm{N}$ and $\mathrm{S}$ [25] is shown in table 1. This research aims to get the characteristic of rice straw and coconut shell as biobriqutte and find the effect of moisture content and caloric value to resistance of solid waste produced.

\section{RAW MATERIAL CHARACTERISTICS}

Raw materials and other supporting materials that will be used as fuel must have continuous availability and characteristics to be burned,

\section{A. Raw Materials Availability}

Muara telang Village community is located in Banyuasin, South Sumatera and $90 \%$ of the people work in agriculture and plantation [3]. The people plant rice 2-3 times a year. Post-harvest leaves haystack ready to be used or burned. Burning straw impacts environmental pollution such as smoke and $\mathrm{CO} 2$ emission [14]. In the plantation, Muara Telang Village community plat coconut and coconut harvest once in a year. The people exploit coconut as copra and leaves stacked coconut as waste. Some of the people use it as char and sold become adding family income. The raw materials availability and the area in the Muara Telang Village shown in table 2.

\section{B. Raw Material Specification}

1) Rice Straw: Straw is the vegetative part of the rice plant (stem, leaf, stem panicle). At harvest time, it was uncollected. 
Straw as fuel produced calories (heat) relatively low but forms smoke and ash a lot. Straw used as additional material in precarious industry, brick and pottery [12]. The weakness of straw was quickly burned, smoky, combustion fly easy, and required continuous maintenance [13]. In the straw burning activity, the risk of fire was very large when the fire was not manned continuously.

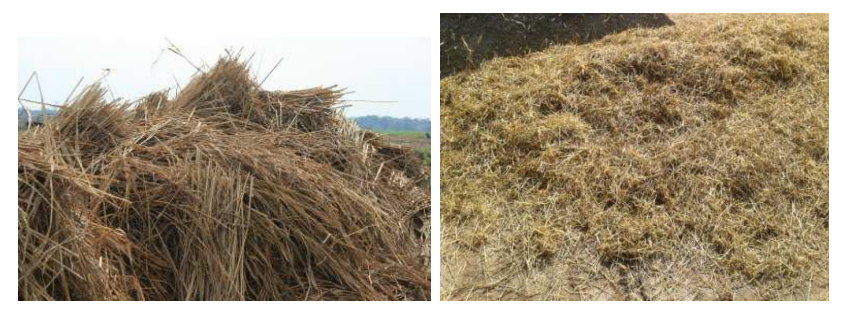

Fig. 1 Rice Straw

Combustion and exhaust straw outside the field has been common to do since intensively cultivated rice twice a year, followed by the planting of crops or horticulture at the end of the dry season [3]. In this condition the paddy soil less gained organic matter from crop residues. The using of high doses inorganic fertilizer without being offset by the addition of organic matter to the soil result less than $10 \%$ soil organic matter content [5]. In America, Di Amerika Serikat, agricultural land has high organic matter content, ranging from 1.4 to $3.6 \%$ [4].

Rice straw has energy when calories were processed through the carbonization process can be used as an energy source to heat the home appliances such as coal [13]. Coal briquettes were less favored due to the high heat generated damage cookware and impractical. Instead, briquettes of straw had enough heat and do not damage the stuffs [6].

2) Rice Straw Characteristics: Rice straw consists of leaves, leaf sheaths, and sections. These three elements were relatively strong due to contain silica, high cellulose and long time decomposition. However, when rice straw treated certainly would change the structure [11]. Straw contains around $40 \% \mathrm{C}$ and remodel easily, biologically, it was a substrate for the growth of soil microorganisms, while the rice straw buried in field then there occurred biochemical reactions in the soil such as (a). Soil reduction related to electrical chemical changes, (b). Immobilization and fixation $\mathrm{N}$, (c). Acid organics production,(d). Release gas $\mathrm{CO}_{2}, \mathrm{CH}_{4}$, $\mathrm{C}_{2} \mathrm{H}_{4}$ and $\mathrm{H}_{2} \mathrm{~S}$ [6] these process affect the availability and uptake the nutrients in plants directly or indirectly.

3) Utilization of Rice Straw as a Fuel: Fuel produces calories (heat) relatively low but forms smoke, ash a lot and went up in flames quickly [11], the combustion residues were easy to fly and need continuous maintenance, the risk of fire was very large when the fire was not manned continuously [25], the use of straw as fuel for the hearth only possible in rural areas, in houses which separated from one another by distances between houses more than $40 \mathrm{~m}$. Utilization of rice straw as fuel was also widely found in China, Nepal, Bangladesh, India and Pakistan [9].

4) Coconut Shell: Utilization of coconuts was only used generally as copra, and coconut oil for domestic use, whiles the other byproducts such as coconut shell had not been so much exploited. The coconut shells are used to be fuel for domestic purposes in a small part and copra fumigation. One of the products of economic value created and coconut shell was activated charcoal [19]. Because of a high calorific value of coal and even exceed, the coconut shell was chosen as an additive ingredient to improve the fuel value of the rice straw biobriquette.

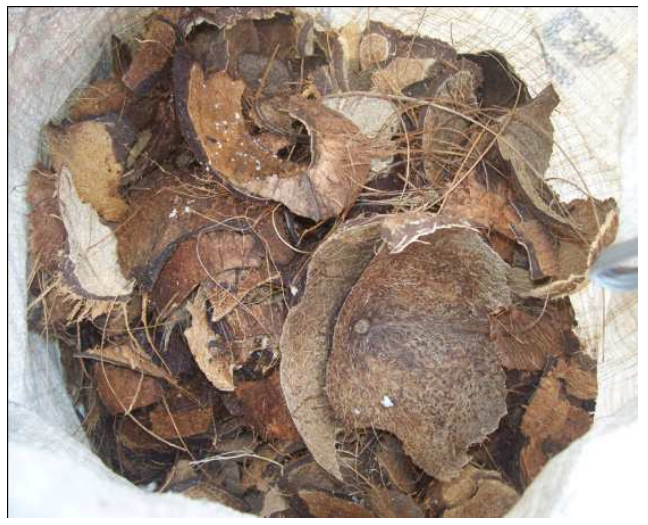

Fig 2. Coconut shells

Shell charcoal which good was black colored uniformly and if were broken off or destroyed, then no shiny outskirts the broken fragment, whereas coconut shell with over burnt cause easily destroyed and when dropped on a hard object will not sound loud and under burnt shell sound was like metal, and the broken fragment was not shiny [28].

Basically, coconut shell contained chemical elements such as carbon, hydrogen and nitrogen in addition to mineral elements such as potassium, calcium and magnesium. Chemical elements such as carbon, hydrogen, and nitrogen were incorporated in the form of main organic compounds i.e. lignin, cellulose and hemicelluloses and materials that can be extracted like sugar, gum and number of ash [28]. The best raw material to manufacture shell briquettes was derived from fresh coconuts. Immature coconut shell was not suitable as a raw material for the manufacture of charcoal and further processed into briquettes, as well as in the wet shell, usually contained impurities such as soil and other substances that were not suitable to be used as raw material for charcoal producing. In the process of making charcoal usually obtained results $30 \%$ of the initial shell weight. Rice straw and coconut shell charcoal was made by manually charcoal process through the closed burning barrel until little ventilation in the charcoal keg, called pyrolysis, which shell went down into the closed tank pyrolysis, then the smoke was condensed to be liquid smoke.

\section{5) Flouring}

Charcoal produced through combustion or pyrolysis then flouring process by using diskmill. Rice straw and coconut shell that had been through the charcoal process followed by sieving with a particular mesh. 
TABLE I

ULTIMATE ANALYSIS OF BIOMASS FROM DIFFERENT HARVEST IN \% DRY MATTER [25]

\begin{tabular}{|c|c|c|c|c|c|c|}
\hline Biomass & Ash & $\mathrm{C}$ & $\mathrm{H}$ & $\mathrm{O}$ & $\mathrm{N}$ & $\mathrm{S}$ \\
\hline Wheat straw & 6,53 & 48,53 & 5,53 & 39,08 & 0,28 & 0,05 \\
\hline Barley straw & 4,30 & 45,67 & 6,15 & 38,26 & 0,43 & 0,11 \\
\hline Maize straw & 5,77 & 47,09 & 5,54 & 39,79 & 0,81 & 0,12 \\
\hline Rice straw & 17,40 & 41,44 & 5,04 & 39,94 & 0,67 & $\mathbf{0 , 1 3}$ \\
\hline Sugarcane bagasse & 3,90 & 46,95 & 6,10 & 42,65 & 0,30 & 0,10 \\
\hline Coconut shell + fibre & $\mathbf{1 , 8 0}$ & 51,05 & 5,70 & 41,00 & $\mathbf{0 , 3 5}$ & $\mathbf{0 , 1 0}$ \\
\hline Potato stalks & 12,92 & 42,26 & 5,17 & 37,25 & 1,10 & 0,21 \\
\hline Beet leaves & & 40,72 & 5,46 & 39,59 & 2,28 & 0,21 \\
\hline Barley chaff & 5,43 & 46,77 & 5,94 & 39,98 & 1,45 & 0,15 \\
\hline
\end{tabular}

TABLE I

STRAW AND COCONUT SHELL PRODUCTION IN MUARA TELANG DISTRICT [3]

\begin{tabular}{|c|c|c|c|c|c|c|c|c|c|}
\hline & \multirow{2}{*}{ Villages } & \multicolumn{2}{|c|}{ Commodities } & \multicolumn{2}{|c|}{ Areas (ha) } & \multicolumn{4}{|c|}{ Productions (ton) } \\
\hline & & Rice & Coconut & Rice & Coconut & Rice & Straw & Coconut & Coconut shell \\
\hline 1 & Telang Lubuk & V & & 452 & & 2.1 & 1.7 & 0.0 & 0.0 \\
\hline 2 & Terusan Dalam & $\mathrm{V}$ & V & 1026 & 307.8 & 4.8 & 3.8 & 18.0 & 2.5 \\
\hline 3 & Karang Anyar & V & & 1270 & & 6.0 & 4.8 & 0.0 & 0.0 \\
\hline 4 & Muara Telang & $\mathrm{V}$ & $\mathrm{v}$ & 635 & 190.5 & 3.0 & 2.4 & 11.1 & 1.5 \\
\hline 5 & Terusan Tengah & V & $\mathrm{v}$ & 606 & 181.8 & 2.9 & 2.3 & 10.6 & 1.5 \\
\hline 6 & Sumber Jaya & V & $\mathrm{v}$ & 882 & 882 & 4.2 & 3.4 & 51.6 & 7.1 \\
\hline 7 & Marga Rahayu & V & $\mathrm{v}$ & 1118 & 1118 & 5.5 & 4.4 & 65.4 & 9.1 \\
\hline 8 & Sumber Mulya & $\mathrm{V}$ & & 2264 & 679.2 & 10.5 & 8.4 & 39.7 & 5.5 \\
\hline 9 & Sumber Hidup & $\mathrm{V}$ & & 1778 & 533.4 & 8.0 & 6.4 & 31.2 & 4.3 \\
\hline 10 & Telang Rejo & $\mathrm{V}$ & & 1812 & 543.6 & 8.5 & 6.8 & 31.8 & 4.4 \\
\hline 11 & Telang Jaya & V & & 1525 & 457.5 & 7.2 & 5.8 & 26.8 & 3.7 \\
\hline 12 & Telang Makmur & V & & 1895 & 568.5 & 8.5 & 6.8 & 33.3 & 4.6 \\
\hline 13 & Telang Karya & V & & 3160 & 948 & 13.5 & 10.8 & 55.5 & 7.7 \\
\hline 14 & Panca Mukti & $\mathrm{V}$ & & 1425 & 427.5 & 6.5 & 5.2 & 25.0 & 3.5 \\
\hline 15 & Mukti Jaya & V & & 2000 & 600 & 9.5 & 7.6 & 35.1 & 4.9 \\
\hline 16 & Karang Baru & V & & 2064 & 619.2 & 9.7 & 7.8 & 36.2 & 5.0 \\
\hline 17 & Mekar Sari & V & & 1897 & 569.1 & 9.5 & 7.6 & 33.3 & 4.6 \\
\hline 18 & Sri Tiga & V & $\mathrm{v}$ & 674 & 202.2 & 4.7 & 3.8 & 11.8 & 1.6 \\
\hline 19 & Muara Telang Marga & $\mathrm{V}$ & $\mathrm{v}$ & 786 & 235.8 & 3.7 & 3.0 & 13.8 & 1.9 \\
\hline 20 & Terusan Muara & V & $\mathrm{v}$ & 1162 & 348.6 & 6.2 & 5.0 & 20.4 & 2.8 \\
\hline 21 & Mekar Mukti & V & $\mathrm{v}$ & 836 & 250.8 & 4.0 & 3.2 & 14.7 & 2.0 \\
\hline 22 & Telang Indah & $\mathrm{V}$ & $\mathrm{v}$ & 700 & 210 & 4.0 & 3.2 & 12.3 & 1.7 \\
\hline \multicolumn{4}{|c|}{ Total } & 29967 & 9873.5 & 142.5 & 114.0 & 577.6 & 80.0 \\
\hline
\end{tabular}

C. Raw Materials specifications as materials to note are [10]:

1) Calorific Value: Calorific value was a measure of heat or energy produced, and measured as the gross calorific value or net calorific value.

2) Volatile matter: Volatile matter (VM) or fly ash effect on the combustion of solid fuels. The more content of volatile matter in the solid material of the fuel made easier to burn and light up [27].
3) Water Content:The water content measurement was the water content in solid fuels. Water content in the solid fuel became greater when calorific value was getting smaller.

4) Ash Content: Ash content in the solid fuel was not flammable mineral that remains after the combustion process and the accompanying reactions completed. ash made lower quality solid fuel due to lower heating value.

5) Combustion Characteristics: According Samsiro, the research results showed that the factors affect the combustion characteristics of solid materials (biobriquette), 
among others [27]: the rate of combustion in which biobriquette combustion was the fastest on biomass composition that had a lot of content of substances volatile [7]. The more volatile matter content of the solid fuel (biobriqutte) hence the easier it was on fire biobriquette [27], so the faster firing rate was able to be measured from fuel weight changes and length of time it took to fuel ashes. The high number of calorific value content fuel in combustion effected achieving high temperature, but the achievement of the optimum temperature took long time.The greater fuel bulk density then burn rate would stay longer. Thus the solid fuel which had a large density had a longer firing rate and a higher calorific value than the solid fuel that had a lower specific gravity [23]. Utilization of rice straw and coconut shell as fuel to be biobriquette certainly produced lower levels of pollutants, achieving the fastest combustion temperature and flammability when lighted up [24].

6) Heat: Heat was defined as the heat energy possessed by a substance. In general, for detecting the presence of heat possessed by an object measured the temperature of the object [15]. If the temperature was high, the heat contained by the object was very large, and if the temperature was low, the heat contained slightly. Heat was a form of energy that can be transformed from one form to another form. Based on the Law of Conservation of Energy, the energy can be transformed into electrical energy and heat energy instead of heat energy could also turn into electrical energy.

7) Bomb Calorimeter: Bomb calorimeter was a device used to measure the amount of heat (calorific value) which was released on complete combustion (in excess $\mathrm{O}_{2}$ ) a compound, groceries, fuel. A number of samples were placed in tubes submerged in oxygenated medium heat absorber (calorimeter), and samples would be burned by the fire power of a metal wire inserted in the tube. Number of samples in a space called "BOMB" and ignited or burned with electric ignition system so that the sample was burned out and generate heat.

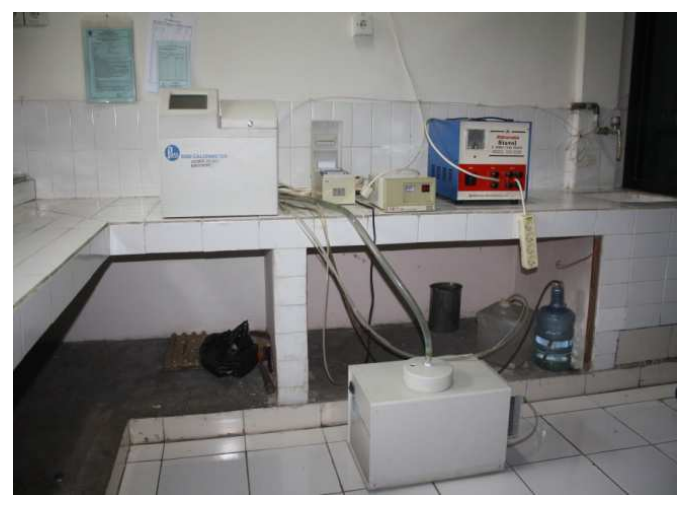

Fig. 3. Bomb Calorimeter

8) Drying Process:Drying process meant removing water from a substance. The process of drying applied if the material was dried lost a piece or all of the water it contained [26]. The main processes that occurred in the evaporation process were drying. Evaporation occurred when water was contained by a material evaporated, i.e., if the heat was given to the material. This heat could be provided through a variety of sources, such as wood, oil and gas, new charcoal or solar power. Drying could also take place in other ways, namely by breaking bonds water molecules contained in the materials [22]. If the bonding of water molecules that consist of basic elements of oxygen and hydrogen solved, then the molecule would be out of the material [23]. As a result, the material would lose the water it contained. This method was also called drying [13], [24]. To break the bonding of oxygen and hydrogen used microwave. Microwaves spread at high frequencies. When adjusted microwave equivalent vibration of water molecules there would be a resonance that was bonding the molecules of oxygen and hydrogen vibrated strongly at the microwave frequencies were given so that the bond ruptured [14]. This causes the water evaporated. The same process occurred in the microwave that was used for cooking food. Drying using heat energy was drying by using solar. In the solar system, the material would be exposed to solar rays directly or indirectly. Water vapor was removed from the drying occurred through air flow. Air flow Process due to the pressure difference caused of air density differences, because the air was the only medium so very easy to obtain and did not require operational costs. Therefore, to understand how the process of drying occurred needed air properties.

9) Air Moisture: Most components in the air are oxygen, nitrogen, and water vapor. Oxygen and nitrogen did not affect the air humidity, while the moisture content affected the humidity. Less air containing water vapor was stated to air dry, while air containing water vapor was stated moist air [13].

Each element in the air, including water vapor, affected air pressure. At a certain value of the air pressure, the maximum pressure of water vapor that can be achieved was called the saturation pressure. If the pressure exceeded the pressure of saturated water vapor would cause reestablish water bead. If the temperature was raised, the saturated pressure would also increase. Therefore we defined the pressure saturated as vapor pressure of water above the surface of the boiling water in a kettle enclosed without air.

Moisture was a term related to the water content in the air. The air stated to have high humidity when contained high water vapor, and vice versa. Mathematically, the humidity was connected as the weight ratio of water vapor in air volume compared to the weight of dry air (air without water vapor) in the same volume. State of temperature, pressure and water vapor content of the air was known as the air quality [7]. Once the air quality was known, then we could assess the ability of the air to evaporate in the material, because the material to be dried was always in a certain quality of air.

Based on everyday experiences we got that the number of air only were able to dry a material or evaporated the water from a material if the material was not a hundred percent humidity. In other words, the ability of air to evaporate the water in the drying process of a material was the maximum when the air was dry and became zero when the air was saturated with water vapor. Under normal circumstances, not one hundred percent air dry or moist, so the air was still able 
to perform the drying process when the material was placed in water containing it [13].

\section{RESEARCH METHODOLOGY}

\section{A. Materials and Equipments}

1) Materials used: (1) Rice straw got from the Muara Telang village, Banyuasin.; (2) Coconut shells got in the Muara Telang village, Banyuasin, (3) a mixtured Eschka $(\mathrm{MgO}+\mathrm{Na} 2 \mathrm{CO} 3=2: 1),(4) \mathrm{BaCl} 2.2 \mathrm{H} 2 \mathrm{O} 10 \%$ solution $(10$ grams $\mathrm{BaCl} 2.2 \mathrm{H} 2 \mathrm{O}$ solution (pa) in $100 \mathrm{ml}$ distilled water), (5) $1: 1 \mathrm{HCl}$ solution (a mixture of $500 \mathrm{ml}, 250 \mathrm{ml}$ concentrated $\mathrm{HCl}(\mathrm{HCl}$ spgr 1.19) with $250 \mathrm{ml}$ of distilled water and a solution of $500 \mathrm{ml}$ of $1: 9 \mathrm{HCl}$, mixing $50 \mathrm{ml}$ of concentrated $\mathrm{HCl}(\mathrm{HCl}$ spgr 1.19) with $450 \mathrm{ml}$ of distilled water., (6) $0.02 \%$ methyl Orange (Dissolve $0.02 \mathrm{~g}$ of methyl orange in $100 \mathrm{ml}$ of hot water then strain), (7) $22 \% \mathrm{Na} 2 \mathrm{CO} 3$ solution (Dissolve 60 grams or 22 grams of crystal $\mathrm{Na} 2 \mathrm{CO} 3.10 \mathrm{H} 2 \mathrm{O}$ anhydrous $\mathrm{Na} 2 \mathrm{CO} 3$ in $100 \mathrm{ml}$ of distilled water, (8) $10 \% \mathrm{NaOH}$ solution (Dissolve $10 \mathrm{~g} \mathrm{NaOH}$ in 100 $\mathrm{ml}$ of distilled water. (9) Oxygen with a purity of more than $99.5 \%,(10)$ a certified standard benzoic acid (calorific value of $6318 \mathrm{cal} / \mathrm{g}$ )

2) Equipments used: (1) porcelain cup 4 pieces, (2) Bottle weigh with special lid, height $22 \mathrm{~mm}$ and diameter $44 \mathrm{~mm}$ 10 pieces, (3) Platina cup 4 pieces, (4) a Desiccator, (5) a chemistry cup, (6) a Brace cup, (7) an Analytical Balance, (8) Filter paper, (9) a rotary stirrer, (10) an Oven dryer $\left(200^{\circ}\right.$ C), (11 ) a Muffle Furnace $\left(2000^{\circ} \mathrm{C}\right)$, (12) a Unit of Automatic Calorimeter.

\section{B. Treatment and Study Design}

1) Raw Materials Preparation: preparation materials included drying, size reduction, and screening aimed to prepare the raw materials to be used as fuel (biobriquette) in order to get a good briquette product.

2) Drying Raw Materials: Drying raw material, rice straw and coconut shell, aimed to eliminate free moisture contained in the raw material. Drying was carried out at a temperature of $110^{\circ} \mathrm{C}$ in the oven for 1 hour.

3) Raw Materials Size Diminution: rice straw and dried coconut shell still have a relatively large size, the size reduction of the raw materials is done using a grinding mill.

4) Raw Materials Carbonization Process: after drying, the raw material should be done on the carbonization process to increase the calorific value of the fuel (biobriquette). For rice straw carbonization process with temperature was done $500^{\circ} \mathrm{C}$ for 15 minutes, while for coconut shell with $650^{\circ} \mathrm{C}$ for 30 minutes.

5) Sieving: Sieving raw materials was done to obtain uniformity of size is -60 mesh materials. This screening had done by using a sieving.

\section{Raw Materials Analysis;}

Preliminary analysis of raw materials included water content analysis, the analysis of volatile matter content, ash content analysis, and determination of calorific value. These analyses were performed both on rice straw and coconut shell.

\section{1) Water Content Analysis (ASTM D 3173-03)}

This analysis was conducted to determine the water content contained in the raw materials section. Analysis of the water content in the raw material both rice straw and coconut shell by calculating the weight of the raw material after heating at a temperature of $110 \mathrm{oC}$ for 1 hour in the oven. The steps were performed to determine water content in the raw material; (1) Preheated the empty weighing bottle inside the oven, closed the bottle then cooled in a desiccator for 15-30 minutes, (2) weighed \pm 1.000 gram sample into the bottle, (3) entered the bottle included contents (open the lid) into a preheated oven $104 \mathrm{oC}$ to $110 \mathrm{oC}$,. (4) Heated the bottle containing the sample weights for \pm 1 hours. (5) Opened the oven, and quickly closed the dry weighing bottle and cooled in a desiccator. (6) Weighed immediately if it had reached room temperature. (7) calculated the value of the water content by the formula [16]:

$$
\text { Water Content }(\%)=\frac{m_{2}-m_{3}}{m_{2}-m_{1}} \times 100 \%
$$

where:

$\mathrm{m} 1=$ weighing bottle and lid mass $(\mathrm{gr}), \mathrm{m} 2$ = weighing bottle + lid + sample before heating mass (gr), m3 = mass of weighing bottle + lid + sample after heating $(\mathrm{g})$.

2) Ash Content Analysis (ASTM D 3174-04): Ash content was not flammable inorganic material remaining after the sample was burned at a temperature of $450^{\circ} \mathrm{C}$ for 1 hour and at a temperature of $750^{\circ} \mathrm{C}$ for 2 hours in a furnace. The steps were performed in the determination of ash content in the raw materials were: (1) Considered \pm 1.000 gram sample with 60 mesh sieve into a cup that was already known weight and closed quickly. (2) Put the cup already containing samples (open the lid) in a muffle furnace to cool and then reheated furnace temperatures up to $450^{\circ} \mathrm{C}-500^{\circ} \mathrm{C}$ for 1 hour. (3) Heated the sample to a temperature muffle furnace reached $700^{\circ} \mathrm{C}-750^{\circ} \mathrm{C} \pm 1$ hour. (4) Repeated the end of the heating at a temperature about 2 hours or until all the samples perfectly into ashes. (5). Lifted the cup from the furnace, put the lid on the cup and metal plates.

(6) Refrigerated for 10 minutes, then place in a desiccator. (7). weighed dish containing cold ashes. (8) Calculated the ash content by formula [17]

$$
\text { Ash Content }(\%)=\frac{m_{3}-m_{1}}{m_{2}-m_{1}} \times 100 \% \text {......(2) }
$$

Where:

$\mathrm{m}_{1}=$ empty cup weight $(\mathrm{gr}), \mathrm{m}_{2}=$ cup with sample weight (gr), $\mathrm{m}_{3}=$ cup with ash weight (gr).

3) Volatile Matter Content Analysis (ISO 562-1998): Volatile matter was part of the briquettes when heated at certain temperature turned into gas. Determination of the volatile matter content contained in the raw material was done by calculating raw material samples weight lost after correction to the water content was heated at a temperature of $900^{\circ} \mathrm{C}$ for 7 minutes in a furnace without air contact. The 
steps were performed in the determination of volatile matter in the raw materials were: (1) Put the lid on the cup holder silica and nickel chromium wire, then heated at a temperature of $900^{\circ} \mathrm{C} \pm 10^{\circ} \mathrm{C}$ for $7 \mathrm{~min}$; (2) Lifted cradle and cup of the furnace and let cool on a metal plate for 5 minutes, then put into a desiccator, (3) after cooling, weighed the cup and its lid.; (4) weighed 1,000 grams of sample into the cup; (5) leveled surface sample by tapping the cup slowly; (6) put the cup on the stand in a closed state, (7) the holder was put into the furnace, heated exactly 7 minutes at a temperature of $900^{\circ} \mathrm{C} \pm 10^{\circ} \mathrm{C}$; (8) lifted the holder of the furnace, then placed on a metal plate for 5 minutes and continued in a desiccator. (9) weighed the cup when cold; (10) calculated volatile matter with formula [29]

$$
\text { Volatile Matter }(\%)=\frac{m_{2}-m_{3}}{m_{2}-m_{1}} \times 100 \%-M_{a d}
$$

where :

$\mathrm{m}_{1}=$ cup and lid mass (gram), $\mathrm{m}_{2}=$ cup + lid + sample mass before heating (gram),

$\mathrm{m}_{3}=$ cup + lid + sample mass after heating (gram), $\mathrm{M}_{\mathrm{ad}}=$ water content value $(\%)$

4) Fixed Carbon Analysis (ASTM Standard D 3172-89): Solid carbon content was calculated from the amount of $100 \%$ minus the water content, reduced ash content and reduced levels of volatile matter, with the formula [21]:

\section{Solid Carbon Content $(\%)=$}

$$
\begin{aligned}
& 100-(\text { water content }+ \text { ash content }+ \\
& \text { volatile matter })
\end{aligned}
$$

5) Calorific Value Analysis (ASTM D 5865-07): Calorific value of the raw material was the sum of heat combustion value from the constituent elements of the raw material. The calorific value can be determined by using Bomb Calorimeter equipment. The steps were performed in the determination of raw material calorific value was [18]: (1) Weighed 1 gram sample into the cup, (2). put into Bomb Calorimeter hook, (3) put $10 \mathrm{~cm}$ cotton yarn burner on the wire connected the two poles of the bomb head, twisted the yarn until the tip touched the sample, Bomb head which already contained a sample inserted into the bomb Calorimeter, then rotated until closed and locked, (4) pressed "start" bottom, then "continue", entered name code or ID sample then pressed enter, see ID bomb, adjusted bomb head code then pressed enter and type the sample weight then enter, automatically the tool would analysis the sample and counted it.

6) Sulfur Total Content Analysis Eschka Method (ASTM D.3177-02 (06)): (1) Weighed 1.000 grams sample into a dish contained 3 grams of a mixture Eschka. Stirred then covered with 1 gram mixture Eschka, (2) Heated the sample into a muffle furnace started from room temperature and then slowly elevated temperature till $800 \pm 25^{\circ} \mathrm{C}$ for 1 hour and heated at this temperature \pm 1.5 hours until the mixture melted perfectly (at a time stirred look no further black particles), (3) Cooled at room temperature, dissolving remelting with $100 \mathrm{ml}$ hot water in a beaker $200 \mathrm{ml}$, heated into hot plate for $1 / 2-3 / 4$ hours, stirring occasionally. (4)
Filtered with filter paper dekatansi (resistant material did not dissolve in the beaker as much as possible), washed insoluble materials with hot water. After several washes, moved material onto filter paper and washed again with hot water till five times. (5) diluted the filtrate to $250 \mathrm{ml}$ added methyl orange, neutralize with $\mathrm{NaOH}$ solution or $\mathrm{Na}_{2} \mathrm{CO}_{3}$ then added $\mathrm{HCl}$ solution $1 \mathrm{ml}$ (1:9), boiled and added $10 \mathrm{ml}$ or more $\mathrm{BaCl}_{2}$ solution with pipette slowly while stirring (the addition of $\mathrm{BaCl}_{2}$ had excess), (6) Boiling back the solution for 15 minutes and let stand for 2 hours above the bath or leave overnight. Filtered with filter paper ash-free (Whatman filter paper no.42) and wash with hot water until the filtrate did not form sludge when $\mathrm{AgNO}_{3}$ solution added, (7) Put the filter paper containing the sludge into the cup porcelain that had been known weight then burned gradually in muffle furnace and lighted up at a temperature of $800 \pm$ $25^{\circ} \mathrm{C}$, (8) Cooled in a desiccator, and then weighed. Calculation using the formula [20]:

$$
\text { SulfurTotal Content }(\%)=\frac{\left(m_{1}-m_{3}\right) \times 13,738}{m_{1}} \ldots \ldots \text {... }
$$

Where:

$\mathrm{m}_{1}$ was biobriquette sample mass adalah berat contoh in gram, $\mathrm{m}_{2}$ was cup and $\mathrm{BaSO}_{4}$ mass in gram, $\mathrm{m}_{3}$ was empty cup mass in gram.

\section{RESULTS AND DISCUSSION}

In this study used rice straw and coconut shells from Muara Telang village, Banyuasin had carbonization process. Observations were made on the basis of raw materials with 1 gram sample size of 60 meshes which had carbonization process, both rice straw and coconut shell. Each sample was duplicated for retibility. Coconut shells were economically due to the price of coconut shell charcoal relatively expensive. The proximate analysis results of raw materials shown in Table 4 below:

TABLE 4.

THE PROXIMATE ANALYSIS RESULTS OF RAW MATERIALS

\begin{tabular}{|c|l|c|c|}
\hline \multirow{2}{*}{ No } & \multicolumn{1}{|c|}{ Parameters } & \multicolumn{2}{|c|}{ Raw Materials } \\
\cline { 3 - 4 } & & $\begin{array}{c}\text { Rice } \\
\text { Straw }\end{array}$ & $\begin{array}{c}\text { Coconut } \\
\text { Shell }\end{array}$ \\
\hline 1 & Total moisture (\%) & 18.98 & 10.55 \\
2 & Inherent moisture( \%) & 11.58 & 6.17 \\
3 & Ash (\%) & 61.96 & 3.22 \\
4 & Volatile matter (\%) & 12.29 & 10.85 \\
5 & Fixed carbon (\%) & 15.61 & 78.32 \\
6 & Total sulfur (\%) & 0.45 & 0.08 \\
7 & Gross calorific value & 1525.5 & 7283.5 \\
& (kcal/kg) & & \\
\hline
\end{tabular}

Despite having a low value of volatile matter, high calorific value and the smoke was not too much. According to D.O. Hall and RP Overend (1987) in the book of Biomass Regenerable Energy, sulfur content in rice straw was $0.13 \%$ (in the dry state had not carbonized) but in this experiment the total sulfur of $0.45 \%$ obtained much differently after carbonization process. It also happened to coconut shell, so after carbonizing the total sulfur content increased. The 
method used to measure the levels of sulfur was analysis of total sulfur analysis by Eschka (ASTM D.3177-02 (06)).

Combustion values obtained from straw was much lower than the fuel value of coconut shell. According to Kirk Otmer (1979) value of coal ranges between 4000-8000 cal / $\mathrm{g}$ which was Antrhracite coal - lignite provided good heat but had a high sulfur content of $0.5-2.5 \%$ [8] which caused pollution against sulfur compounds in the air. To reduce dependence on the use of coconut shell as fuel, rice straw and coconut shell should be used as an alternative solid fuel substitute liquid fuels and obtain the fuel with a high fuel value and low sulfur. Nowadays farmers just left and burned rice straw after harvest, the smoke and ash produced from the combustion spread around the stricken area, and caused environmental pollution due to smoke generated.

\section{CONCLUSION}

Straws burn directly will produce smoke and high volatile matter. It can harm the environment and cause pollution. Inversely related to the characteristics of coconut shell, can cause not much smoke and too little volatile matter. It is influenced by the calorific value and the amount of fixed carbon from coconut shell that has a high value. Hence the need for research biobriquette making fuel from straw and coconut shell.

\section{REFERENCES}

[1] Chin Chin Ooi and Kamal M. Siddiqui, Characteristics of Some Biomass Briquettes Prepared Under Modest Die Pressurs, Biomass and Bioenergy 18 (2000) 223-228

[2] Shii Chou-Chuen, Sheau-Horng Lin and Wen-Chung Lu., Preparation and Characteriization of Solid Biomass Fuel Made From Rice Straw and Rice Bran, Fuel Processing Technology 90 (2009) 980-987

[3] BAPPEDA, Banyuasin Dalam Angka, Badan Perencanaan Pembangunan Daerah dan Penanaman Modal Kabupaten Banyuasin, 2010

[4] Stewart, I. T., D. R. Cayan, and M. D. Dettinger, Change in snowmelt runoff timing in western North America under a "business as usual" climate change scenario. Climatic Change, 62 (2005) 217232.

[5] Uphoff, N and A. Gani. Higher yields with fewer external inputs? The System of Rice Intensification and potential contributions to agricultural sustainability. International Journal of Agricultural Sustainability 1 (2003) 38-50.

[6] Yoshida, (1978). Reaksi Jerami pada Tanah Sawah. \{online\}. Available: http://www.wbiconpro.com/15\%5B1\%5D.Siwar.pdf

[7] Naruse, I., Gani, A., Morishita, K., ,Fundamental characteristics on Co Combustion of Low Rank Coal with Biomass" . Nova Science Publishers,inc, New-York, 2001.

[8] Kirk. R.E, and D.F. Othmer, Encyclopidia of Chemical Technology. Third edition. Vol. 6. John Wiley \& Sons. Inc. New York. Pp.224285, 307-323. 1979

[9] Tanaka,N., Takami, M.\&Kubo,T.1983. Properties of Forest Soil Derived from Volcanic on Mt. Fuji and Mt. Amagi III, Chemical Properties. Trans 94th meet. Jpn for soc,735-736 (in Japanese)

[10] Hessley.R.K., Reasoner.J.W and Riley,J.T., Coal and Science., Tenth edition, John Wiley \& Sons. Inc.,New York, pp.182-257.,1986.

[11] Dobermann and T.H. Fairhurst.. Rice Straw Management. Better Crops International, Vol 16, may 2002

[12] Makarim A.K, Sumarmo, Suyanto, Jerami Padi Pengelolaan dan Pemanfaatan. Pusat Penelitian dan Pengembangan Tanaman Pangan. Badan Penelitian dan Pengembangan Pertanian. Bogor, 2007

[13] Suramaythangkoor, T. and Shabbir H.Gheewala. Potensial Alternatives of Heat and Power Technology Application Using Rice Straw in Thailand. Elsivier Applied Energy 87 (2010) 128-133

[14] Blair.Graeme and Rod Lefroy, Sulfur and Carbon Research in Rice Production Systems. Elsevier Field Crops Research 56 (1998) 177181
[15] Zeng.Xianyang, Yitai Ma and Lirong Ma, Utilization of Straw in Biomass Energy in China. Elsivier ScienceDirect, Renewable and Sustainable Energy Reviews II (2007) 976-987

[16] American Society for Testing and Material.2003. Analisa Kadar Air. United State Of America: diterjemahkan oleh Dinas Pertambangan Provinsi Sumatera Selatan.

[17] American Society for Testing and Material.2004. Analisa Kadar Abu United State Of America: diterjemahkan oleh Dinas Pertambangan Provinsi Sumatera Selatan.

[18] American Society for Testing and Material.2007. Penentuan Nilai Kalor dengan Teknik Isoperibol. United State Of America: diterjemahkan oleh Dinas Pertambangan Provinsi Sumatera Selatan.

[19] Ekalinda, Oni. Teknologi Pembuatan Arang Tempurung Kelapa. Balai Pengkajian Teknologi Pertanian (BPPT) Pekanbaru. Riau, 2010

[20] American Society for Testing and Material.2006. Analisa Kada Belerang Total Cara Eschka. United State Of America: diterjemahkan oleh Dinas Pertambangan Provinsi Sumatera Selatan.

[21] American Society for Testing and Material.1989. Analisa Fixed Carbon. United State Of America: diterjemahkan oleh Dinas Pertambangan Provinsi Sumatera Selatan.

[22] Carlos Romel M and Do Ba Khang, Characterization of Biomass Energy Projects in Southeast Asia. Elsivier ScienceDirect, Biomass and Bioenergy 32 (2008) 525-532

[23] Lim Jeng Siun. Zainuddin Abdul Manan. Sharifah Rafidah Wan Alwi dan Haslenda Hashim. A Review on Utilization of Bimass From Rice Industry As A Source of Renewable Energy. Elsivier. Renewable and Sustainable Energy Reviews 16 (2012) 3084-3094

[24] Wiliam. A, J.M.,Jones. L.Ma and M.Pourkashanian, Pollutans From The Combustion Science. Elsivier. Progress In Energy And Combustion Science 38 (2012) 113-137

[25] Hall, D.O and R.P Overend.1987. Biomass Regenerable Energy. John Wiley and Sons Ltd: Great Britain

[26] Hasibuan, Rosadaneli, (2005). Proses Pengeringan. \{Online\} Available : http://repository.usu.ac.id/bitstream/123456789/1359/1/ tkimia-rosdanelli2.pdf .

[27] Samsiro, M., Kualitas Sifat-sifat Penyalaan dari Pembakaran Briket Tempurung Kelapa, 2011. \{online\}. Available. http://repository.upnyk.ac.id/346/1/Kualitas_Sifatsifat_Penyalaan_dari_Pembakaran_Briket_Tempurung_Kelapa,.pdf

[28] Palungkun, R. Aneka Produk Olahan Kelapa. Cetakan ke Sembilan. Penebar Swadaya. Jakarta, 2003

[29] International Organization for Standardization.(ISO 562-1998), Methods for analysis and testing of coal and coke. Determination of volatile matter content. ISBN 0580-29667-6 